\title{
Marketed Surplus of Coffee by Smallholder Farmers in Seka Chokorsa District, Jimma Zone, Ethiopia: Determinants Analysis
}

\author{
NASIR ABABULGU ABASIMEL \\ Department of Agribusiness and Value Chain Management, Wollega University, P.O.BOX: 38, Wollega \\ University, Shambu, Oromia, Ethiopia
}

\begin{abstract}
Coffee is mainly produced for market and is an important export cash crop in the study area. This study analyzed the determinants of sundried coffee marketed surplus by smallholder farmers in Seka chokorsa district of Jimma Zone. Both data sources and types, primary and secondary, qualitative and quantitative, were used to achieve the objective of the study under consideration. These data were collected from 124 smallholders coffee producers who were randomly selected in the study area using questionnaires and other stakeholders who directly or indirectly deal with coffee production and supply were interviewed. Multiple linear regression model was used to analyze the determinants of sundried coffee marketed surplus as all coffee producers were supplied coffee to the market and the assumptions of OLS were tested which indicated the absence of violations due to fitness of the model with data collected. The result of multiple regression model revealed that coffee farming experience, family size, land size, coffee market information and membership to the cooperatives affected marketed surplus of sundried coffee positively and significantly whereas sex of the household head and distance from the nearest market affected negatively and significantly. Therefore, policy needs to emphasize at encouraging women to increase their coffee supply and expanding the accessibility of market infrastructure to close the gap, and further, strengthening farmers cooperatives, increasing the production and productivity of coffee land, developing farmers experience through skills and knowledge, and facilitation of market and information access are highly recommended in order to increase coffee marketed surplus by smallholder coffee farmers in the area.
\end{abstract}

Keywords: Determinants, Sundried Coffee, Marketed surplus, Multiple Linear Regression Model

DOI: $10.7176 / \mathrm{DCS} / 10-8-02$

Publication date:August $31^{\text {st }} 2020$

\section{INTRODUCTION}

The coffee subsector of Ethiopia has been and continues to be the foundation for the country's agricultural and economic development. The subsector accounts for over 35\% of agricultural foreign exchange earnings and about $4 \%$ of agricultural Gross Domestic Product (Agric. GDP), provides income to over 15 million people in the country through provision of jobs for farmers, local traders, processors, transporters, exporters and bankers (FAOSTA, 2011). Currently, Ethiopia exports 170,000 tons and has a domestic consumption is estimated to be about $50 \%$ of the total production (Aklilu and Ludi, 2010). The total land area of about 5,68,740 (3.91\%) hectares are covered by coffee, from which a total volume of about 4,199,801.56 quintals of coffee are obtained, from $4,723,483$ private peasant holdings in the agricultural year (CSA, 2014/2015).

Jimma Zone is one of the coffee growing zones in the Oromia Regional State. Currently, the total land area of about 97,155 hectares are covered by coffee, from which a total volume of about 803,224 quintals of coffee are obtained, from 444,216 private peasant holdings in the agricultural year (CSA, 2014/2015). The zone covers a total of $21 \%$ of the export share of the country and $43 \%$ of the export share of the Oromia Region (JZARDO, 2008). In terms of the top 25 woredas, Oromia dominates with 18 of the top 25. More specifically, Jimma zone in Oromia has five of the top 25 producing woredas (IFPRI 2015).

According to Elias (2005), the coffee bean marketing problems were low quality coffee produced by farmers, poor marketing infrastructure and facilities and lack of institutional credit for coffee production and marketing. Though the contribution of the area is high in supplying coffee to domestic and export market, there are many problems determining smallholders in supplying their coffee to the market. Limited access to market facilities, less exposure for market information, infrastructural problem, inadequate support services and problem in transportation services are some the problems resulting in low participation of smallholder farmers in selling their products. More importantly marketed supply of coffee in the study areas is subjected to seasonal variation where surplus supply at the harvest time is the main feature (Bizualem. 2015). Hence, there is a need to analyze factors affecting coffee marked surplus by smallholders to narrow the gap in the area

\section{METHODOLOGY}

\subsection{Description of the study area}

Seka Chokorsa district extends between $7^{0} 20^{\prime}-7^{0} 45^{\prime}$ north latitude and $36^{0} 33^{\prime}-36^{0} 53^{\prime}$ east longitude. It is bordered with Gomma and Mena districts north; Kersa district in northeast; Dedo district in east; with SNNP district in south; Gera district in west and northwest; and Sombo Shabe district in the south west. The total surface area of 
the district is 85,425 hectares and situated in the southern part of Jimma zone. Seka Chokorsa district has a total population of 212,619 during 2008 of which 107,011(50.3\%) were male and 105,607(49.7\%) were female. Most part of the district belongs to subtropical with the altitude of 1500-2300 m a.s.1 (72\%) and highland areas with the altitude ranges from 2300-2800 m a.s.1 (21\%) and the altitude below $1500 \mathrm{~m}$ a.s.1 (7\%) belongs to lowland. The western parts do have cool agro-climate with the mean annual temperature ranges of between $15-18^{0} \mathrm{c}$ and the vast part of the district is classified as subtropical with mean annual temperature ranges of between $18-22^{\circ} \mathrm{c}$. The annual rainfall varies between $1300 \mathrm{~mm}$ and $1700 \mathrm{~mm}$ (BFED, 2015). The location map of the study area is depicted hereunder.

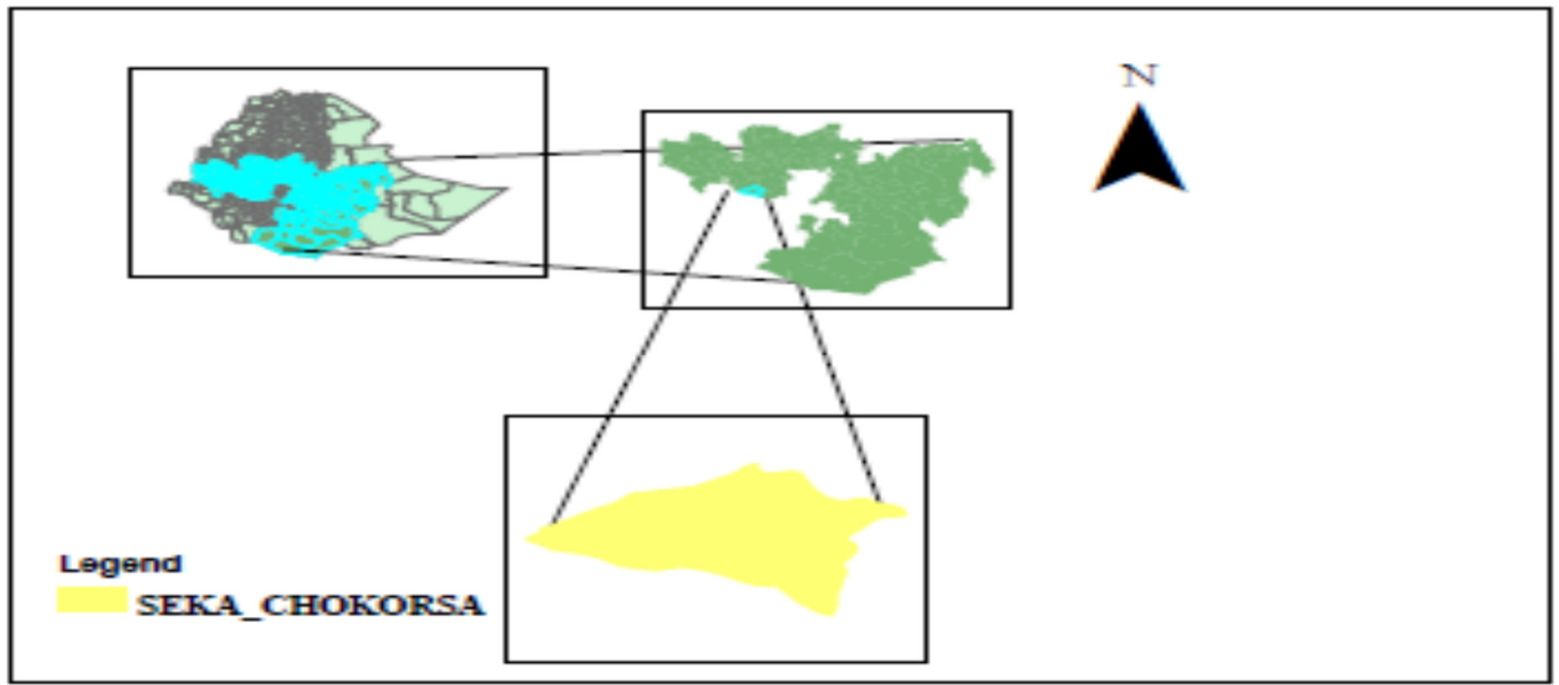

\subsection{Econometric analysis}

\section{Determinants of marketed surplus of coffee}

In order to transform agriculture based economy to industry based economy which further plays a crucial role in economic growth and poverty reduction, smallholder households need to increase their marketed surplus. As marketed surplus of farmers become higher and higher, the level of their income increased and livelihoods are improved. Therefore, analyzing the determinants of marketed surplus is a major component to solve the problems of smallholders.

In this study, multiple linear regression model was used to analyze factors affecting farm level coffee supply to the market in the study area as all coffee producers participate in the market. This model was also selected for its simplicity and practical applicability (Greene, 2000).

Econometric model specification of supply function in matrix notation is the following.

$$
Y=X^{\prime} \beta+U
$$

Where: $Y=$ the marketed surplus by a household

$\mathrm{X}^{\prime}=\mathrm{a}$ vector of explanatory variables (About 12 variables were used in this model)

$\beta=$ a vector of parameters to be estimated

$\mathrm{U}=$ disturbance term

\section{Testing for assumption validation}

The assumptions of OLS estimates were detected to identify whether these assumptions are violated or not. It is necessary to test multicollinearity problem among explanatory variables which seriously affects the parameter estimates. According to Gujarati (2003), multicollinearity refers to a situation where it becomes difficult to identify the separate effect of independent variables on the dependent variable because of existing strong relationship among them. The existence of multicollinearity problem is tested using variance inflation factor (VIF). Thus, Variance Inflation Factor (VIF) is used to check multicollinearity among independent variables. As a rule of thumb, if the VIF is greater than 10 (this will happen if $\mathrm{R}^{2}$ is greater than 0.90 ), the variable is said to be highly collinear (Gujarati, 2003). A measure of multicollinearity associated with the variance inflation factors is computed as:

$$
\operatorname{VIF}\left(X_{i}\right)=\frac{1}{1-R_{i}^{2}}
$$

Where, $R_{i}^{2}$ is the multiple correlation coefficients between explanatory variables, the larger the value of $R_{i}^{2}$ is, the higher the value of VIF (Xi) causing higher collinearity in the variable (Xi). The result of VIF showed that the absence of multicollinearity problem among independent variables because the value of VIF was less than 10 which is 3.57 . So, in this study, there is no multicollinearity problems among independent variables included in model. 
In addition, if there is heteroscedasticity problem (if the error terms do not have a constant variance) in the data set; the parameter estimate of the coefficients of the independent variables cannot be BLUE. Hence, there is a need to test the problem. There are a number of test statistics for detecting heteroscedasticity. According to Guiarati (2003) there is no ground to say that one test statistics of hetroscedasticity is better than the others. Therefore, due to its simplicity Breusch-Pagan test of heteroscedasticity was employed for detecting heteroscedasticity in this study. This test displayed that the presence of homoscedastic in the data set or the error term have constant variance.

The problem of endogeneity occurs when an explanatory variable is correlated to the error term in the population data generating process, which causes, the ordinary least squares estimators of the relevant model parameters to be biased and inconsistent. The source of endogeneity could be omitted variables, measurement error and simultaneity (Maddala, 2001). Both Hausman test and Durbin-Wu-Hausman (DWH) test is applied to check the presence of endogeneity. In the case of Huasman test if there is little difference between OLS and IV estimators, then there is no need to instrument, and we conclude that the regressor is exogenous. If instead there is considerable difference, then we need to instrument and the regressor is endogenous (Cameron and Trivedi, 2009). In the case of just one potentially endogenous regressor with the coefficient denoted by $\beta$, the Huasman test statistics is:

$$
H_{T}=\frac{\left(\hat{\beta}_{I V}-\hat{\beta}_{O L S}\right)^{2}}{\widehat{V}\left(\hat{\beta}_{I V}-\hat{\beta}_{O L S}\right)}
$$

If $\chi 2(1)$ distributed under the null hypothesis that the regressor is exogenous.

In the case Durbin-Wu-Huasman (DWH) test the error term from the first stage added on the structural equations. i.e $y_{1 i}=\beta_{1} y_{2 i}+\dot{x}_{1 i} \beta_{2}+p v_{1 i}+\mu_{i}$, where $\mathrm{v} 1$ is the error term from the first stage equation (Davison, 2000).

This problem can be overcome by using two stages least square (2SLS) method if there is endogeniity problem in the study. The method involves two successive applications. The first stage is made by regressing the suspected endogenous variables over the predetermined or pure exogenous variables to get their predicted values. However, there was no the problem of endogenity or all variables used in the model were exogenous.

The overall goodness of fit of the regression model is measured by the coefficient of determination, $\mathrm{r}^{2}$. It tells what proportion of the variation in the dependent variable, or regressand, is explained by the explanatory variable, or regressor. This $\mathrm{r}^{2}$ lies between 0 and 1; the closer it is to 1 , the better is the fit (Gujarati, 2004). The result showed about $95.76 \%$ of variation in dependent variable is due to variation in in independent variables indicating the better the fit.

\subsection{Variable Selection, Definition, and Hypotheses}

In the course of analyzing determinants influencing coffee marketed surplus, the main task is identifying which factors potentially influence and how (the direction of the relationship) these factors are related with the dependent variables.

\section{Dependent variable}

Volume of Coffee Sales (VCS): It is a continuous dependent variable which was used in the multiple linear regression model. It was measured in $85 \mathrm{KG}$ sack (quintal) and represents the actual supply by coffee farm household to the market in the earlier year.

Independent variables

Sex of the household head (Sex): A dummy variable taking zero if female and one if male for variable to be considered. Male headed households are expected to have positive relation with marketed surplus than female headed one. Tshiunza et al. (2001) determined that male farmers tended to produce cooking banana for market and therefore participated in banana market more than female farmers participate. Further, study conducted by Awol (2010) indicated negative relation between sale volume of poultry and male-headed household. Thus, being male headed household is hypothesized to affect marketed surplus positively.

Education of the household head (HEduc): It is a dummy variable measured in terms of whether the household has a formal education or not which takes a value one if a household have formal education and zero otherwise. Education broadens farmers' intelligence and enables them to perform the farming activities intelligently, accurately and efficiently. Moreover, better educated farmers tend to be more innovative and are therefore more likely to adopt the marketing systems. Formal education enhances the information acquisition and adjustment abilities of the farmer, thereby improving the quality of decision making (Fakoya et al., 2007). Hence, this variable was hypothesized to influence volume of coffee sales positively. Astewel (2010) found that if paddy producer gets educated, the amount of paddy supplied to the market increases, which suggests that education improves level of sale that affects the marketed surplus. Therefore, educated household head is hypothesized to influence marketed surplus positively.

Distance to the nearest market (DMkt): It is the distance of the coffee producer households to the nearest market and it is measured in hours of walking hours. The closer the market, the lesser would be the transportation charges, reduced walking time, and reduced other marketing costs. Those households who are close to market are 
encouraged to have better probability of supplying their sundried coffee to the market there by increasing volume of coffee marketed. It is expected that longer distances increase travel time and travel costs, which affect the marketed surplus negatively due to adverse impact on market participation. Similar issue was studied by Ayelech (2011) on fruit market in Goma woreda identified that poor market access has significant and negative effect on quantity of avocado and mango supplied. In this study distance to nearest market is hypothesized to affect volume of coffee sales negatively.

Coffee farming experience (CFExp): It is the total number of years a farmer stays in production of coffee. A household with better experience in coffee farming is expected to produce more amounts of coffee and, as a result, he is expected to supply more amount of coffee to market. The result from Abraham (2013) implied that as farmers have high potato production experience the amount of potato supplied to the market increased through its effect on potato production. Farmers with longer farming experience are expected to be more knowledgeable and skillful (Ayelech, 2011). Therefore, this variable was hypothesized to positively influence coffee marketed surplus.

Family Size (Family): Family size of a household is a continuous variable measured in terms of number of family members in the household and hypothesized for marketed surplus only. As coffee production is labour intensive activity, coffee production in general and market supply of coffee products in particular is a function of labour. Accordingly, families with more household members tend to have more labor which in turn increase coffee production and then increase coffee market supply. Gezahagn (2010) who found that family size have positive effect on the households' gross income from groundnut production. Abay (2007) found out that marketed supply of vegetables were significantly affected by family size. Thus, family size was expected to influence the volume of coffee supply to the market positively.

Land Size (Land): This refers to the total area of land that a farm household owned in hectares and expected to influence only coffee marketed surplus. In agriculture, land is one of the major factors of production. The more the land a household owns the more he/she produce and supply. The availability of land enables the owner to earn more agricultural output which in turn increases the marketable supply (Desta, 2004). Therefore, land holding and marketed supply are expected to have direct relationship.

Ownership of market transport facilities (OTran): Specifically vehicles, carts and transport animals are used to measure the availability of produce transportation facilities by households. In cases where households owned transportation facilities, the variable took the value of one, and zero if the household did not own any form of transport facility. Owning transportation facilities reduces transportation cost making households to supply more coffee to the market. This variable is expected to have influence on the marketed surplus of sundried coffee positively.

Credit access (Credit): This is a dummy variable taking the value one if the household takes loan and zero otherwise, which indicates credit taken for coffee production. Access to credit would enhance the financial capacity of the farmer to purchase the inputs, thereby increasing coffee production and market share size. Bizualem et.al (2015) found that those farmers who have got credit access increase their coffee marketed surplus. Alemnewu (2010) and Muhammed (2011) who found that if pepper and teff producer gets credit, the amount of pepper and teff supplied to the market increased. Hence, it was hypothesized that farmers' access to credit would influences marketed surplus positively.

Access to coffee market information (MInfo): The variable is considered as dummy. Assign one if a household got information and zero if not. Farmers marketing decisions are based on market price information, and poorly integrated markets may convey inaccurate price information, leading to inefficient product movement. Those who have access to dynamic information produce more coffee and supply to the market. Muhammed (2011) who found that if wheat producer gets market information, the amount of wheat supplied to the market increases. Therefore, it was hypothesized that households' market information is positively related to marketed surplus of coffee.

Income from Non/Off Farming Activities (NOFI): It is a dummy variable measured in terms of whether the household obtained income from off and non-farming activities. It is one if the household is involved in non/off farm activities and zero otherwise and was hypothesized to affect only coffee marketed surplus. This income may strengthen farming activity on one side and may weaken it on the other side. Rehima (2006) who found that if pepper producer have non-farm income, the amount of pepper supplied to the market decreases. For this study households' income from non/off farm is assumed to have inverse relation with volume of coffee sales.

Membership to cooperatives (MCoop): It is binary variable and takes the value of one if the household is a member of the cooperatives engaged in the business, otherwise zero. Thus cooperatives improve understanding of members about market and strengthen the relationship among the members. Those who are members of cooperatives might be inspired by additional dividend payment besides on actual commodity price than their counterparts and motivated to increase the quantity of coffee marketed and choose better market channel. Some researchers argue that farmers in groups have an easy access to skills and information which in turn enable them to diversify their income sources and marketing. This happens because the government and donors target not individual farmers but farmer groups and cooperatives. Therefore, this variable was expected to be associated to marketed surplus positively. Bizualem et al. (2015) found that being a member of the coffee cooperative increase 
the level of marketed surplus of coffee.

Livestock (TLU): This is a continuous variable measured in tropical livestock unit. Farmers who have a number of livestock are anticipated to specialize in livestock production so that they allocate large share of their land for pasture. Study by Rehima (2006) on pepper marketing showed that TLU showed a negative sign on quantity of pepper sales. On the other hand, it is assumed that household with larger TLU have better economic strength and financial position to purchase sufficient amount of input (Kinde, 2007). But for this study TLU was hypothesized to influences volume of coffee sales negatively.

\subsection{Econometric Models Outputs}

\subsubsection{Determinants of Sundried coffee marketed surplus}

Coffee is mainly produced for market and is an important export cash crop in the study area. According to the result of this study, all sample households are suppliers of coffee to the market. Analysis of determinants of marketed surplus of sundried coffee has made it possible to identify determinants constraining coffee supply to the market. The analysis was done using data obtained from the 124 coffee producing farmers. Multiple linear regression model was employed to identify these factors. For the parameter estimates to be efficient, unbiased and consistent, the assumptions of Classical Linear Regression (CLR) model should hold true. Hence, multicolliniarity, specification error for omitted variables and heteroscedasticity detection test were performed using appropriate test statistics. Breusch-Pagan/Cook-Weisberg test for heteroskedasticity was used to check the problem of heteroscedasticity. This test showed that there is no heteroskedasticity problem indicating constant distribution of the error term $(\mathrm{chi} 2(1)=0.33(\mathrm{P}=0.57))$. Similarly the test for multicollinearity detected the absence of multicollinearity problem since VIF results for all variables included in OLS model are less than 10 with the mean of 3.57. In addition, the test of specification error for omitted variables was undertaken and its result showed that the model has no omitted variable for coffee supplied to the market $(\mathrm{F}=2.08(\mathrm{p}=0.11))$. Therefore, there was no need of employing 2SLS method using standard robust error. The OLS result is presented below.

In this model, twelve explanatory variables were hypothesized and analyzed to determine the determinants of households' sundried coffee marketed surplus. Out of the twelve factors hypothesized to affect marketed surplus of coffee in the study area, seven were found to be significantly affect the dependent variable. Results revealed that coffee farming experience, family size, land size, coffee market information and membership to the cooperatives affected marketed surplus of sundried coffee positively and significantly; whereas sex of the household head and distance from the nearest market affected negatively and significantly (Table 1).

Table 1. Determinants of marketed surplus of sundried coffee

\begin{tabular}{lll}
\hline Volume of coffee sale & Coefficients & Std. Err \\
\hline Sex of the household head(1=male) & $-.378^{*}$ & .224 \\
Education of household head(1=yes) & .144 & .138 \\
Distance to the nearest market (hours) & $-2.397^{* * *}$ & .362 \\
Coffee farming experience(years) & $.097^{* * *}$ & .017 \\
Family size(adult equivalent) & $.229 * * *$ & .066 \\
Land size(hectares) & $.161^{* *}$ & .070 \\
Ownership of transport facility(1=own) & -.287 & .221 \\
Credit access(1=have access) & .130 & .387 \\
Coffee market information(1=yes) & $1.542^{* * *}$ & .281 \\
Non/Off farm income(1=yes) & -.020 & .141 \\
Membership to the cooperatives(1=yes) & $.416^{*}$ & .216 \\
Livestock ( TLU ) & .002 & .032 \\
Constant & 5.649 & .935 \\
\hline
\end{tabular}

Note: Dependent variable is the amount of sundried coffee sold in quintal (one quintal $=85 \mathrm{~kg} \mathrm{sack}$ ). ***,** and * represent statistical significance at $1 \%, 5 \%$ and $10 \%$, respectively. $\mathrm{N}$ is 124 , Adjusted $\mathrm{R}^{2}$ is $95.76 \%$, when $\mathrm{F}(12$, 111) $=232.47$ and Prob $>F=0.000$

Source: Own computation results, 2019

Sex of the household head: Unexpectedly sex of the household head affects marketed surplus of sundried coffee negatively and significantly at less than $10 \%$ significance level. Being male headed household has negative relationship with marketed surplus than female headed one. The result indicated that being male headed household decreases marketed surplus of sundried coffee by 0.378 quintal ( $85 \mathrm{~kg} \mathrm{sack})$, holding all other variables constant or for male headed household, the coffee marketed surplus would be 0.378 quintal lower than for female headed. This might be due to the case that in the study area female headed household engage in coffee production and marketing than in grain production which requires ploughing the land (heavy work) than male headed household. This result is in line with the study conducted by Awol (2010) who indicated negative relation between sale volume of poultry and male-headed household.

Distance to the nearest market: It affected sundried coffee marketed surplus negatively and significantly at less 
than $1 \%$ significance level as expected. The result showed that as the distance from the nearest market increased by one hour, the quantity of sundried coffee supplied to the market decreased by 2.397 quintal, holding all other variables unchanged. This is because as the distance from the market increases, transportation cost also increases to transport coffee which in turn decreases the marketed surplus. The longer distance of the market, the higher would be the transportation charges, increased walking time, and increased other marketing costs. Similar issue was studied by Ayelech (2011) on fruit market in Goma woreda and she identified that poor market access or distance from the market has significant and negative effect on quantity of avocado and mango supplied.

Coffee farming experience: This variable affected quantity of marketed surplus significantly and positively at $1 \%$ significance level. The coefficient for this variable implied that, a one year increase in farming experience leads to a 0.097 quintal increase in marketed surplus of sundried coffee (in $85 \mathrm{~kg}$ sack), while all other factors affect coffee marketed surplus remain the same. This is probably due to the reason that households with better experience in coffee farming produce more amount of coffee and, as a result, supply more amount of coffee to market. This result was in confirmation with the studies by Abraham (2013), Abay (2007), and Ayelech (2011) as production experience affected the amount of potato, avocado and tomato supplied to the market positively. In addition, Bizualem et.al (2015) This variable affected quantity of marketed surplus significantly and positively which implied that a one year increase in farming experience leads to a $1 \%$ increase in marketed surplus of coffee.

Family size: It affected the dependent variable positively and significantly at $1 \%$ significance level. The coefficient is 0.229 indicating that for every unit increase in family size, the quantity of sundried coffee supplied to the market increase by 0.229 quintal, all other variables are kept constant. This is because families with more household members tend to have more labor which in turn increase coffee production and then increase coffee market supply. This result is in line Gezahagn (2010) who found that family size have positive effect on the households' gross income from groundnut production.

Land size: It is one of the variable found to affect coffee marketed surplus significantly and positively at $5 \%$ significance level. Holding all other variables constant, for every hectare increase in land size, the quantity of sundried coffee marketed increase by 0.161 quintal. In agriculture, land is one of the major factors of production. This is due to the more the land a household owns the more he/she produce and supply. The availability of land enables the owner to earn more agricultural output which in turn increases the marketable supply (Desta, 2004).

Access to coffee market information: It affected marketed surplus of sundried coffee positively and significantly at $1 \%$ significant level. On average if coffee producer gets market information, the amount of sundried coffee supplied to the market increase by 1.542 quintal, holding all other variables constant. This suggests that access to market information reduces farmers risk aversion behavior of getting a market and decreases marketing costs of farmers that affects the marketed surplus. The implication is that obtaining and verifying information helps to supply more quantity of coffee. Those who have access to dynamic information produce more coffee and supply to the market. This is in line with Mohammed (2011) who illustrated access to market information by farming households increase marketable supply of teff significantly in Halaba especial Woreda.

Membership to the cooperatives: As hypothesized, membership in cooperative affected marketed surplus of sundried coffee positively and significantly at less than $10 \%$ significance level. The result showed that, other factors held constant, being a member of the cooperative would probably increase the level of marketed surplus of sundried coffee by 0.416 quintal, holding other variables unchanged. Those who are members of cooperatives might be motivated with double payment (dividend payment besides actual price of commodity) than nonmembers and motivated to increase the quantity of coffee marketed. This happens because the government and donors target not individual farmers but farmer groups and cooperatives. Thus cooperatives improve understanding of members about market and motivate them to produce more products. This is in line with Bizualem et al. (2015) found that being a member of the coffee cooperative increase the level of marketed surplus of coffee.

\section{CONCLUSION AND RECOMMENDATION}

The result concluded that female headed households are in a better situation in marketing of coffee compared to male headed implying that a need to further motivating women as well as encouraging men is important in order to increase marketed surplus. The provision of training and extension services should focus on both genders. Distance to the nearest market affected sundried coffee marketed surplus negatively. As the distance from the market increases, transportation cost also increases to transport coffee which in turn decreases the marketed surplus. Hence, the policy intervention need to target at improving road infrastructure to tackle the problem of distance which increases coffee supply to the market. The study also concluded that coffee farming experience affected quantity of sundried coffee marketed surplus positively and significantly. The measure that work on building the capacity of the farmers and developing the skills what farmers have through experience increases coffee supply to the market. Family size another independent variable affected coffee marketed surplus positively and significantly implying that families with more household members tend to have more labor which in turn increase coffee marketed surplus.

Furthermore, land size is one of the variable found to affect coffee marketed surplus significantly and 
positively; and hence, increasing the production and productivity of coffee per unit area of land is better alternative to increase marketed surplus of coffee from available land size. Introduction of improved varieties, application of organic fertilizers, using modern technologies, controlling disease and pest practices should be promoted to increase coffee supply. Access to coffee market information affected marketed surplus of sundried coffee positively. The government intervention should target at strengthening the supportive activities such as information centers and its delivery would also boost coffee supply. In the area, membership to cooperative affected marketed surplus of sundried coffee positively. Organizing farmers under cooperatives from which they acquire knowledge, skills, capacity, knowhow, input access, access to market and information in coffee production and marketing process increases coffee marketed surplus in the area. In general, encouraging both genders, improving road infrastructure, building the capacity and developing the skills of the farmers to increase coffee farmers' experiences, increasing the production and productivity of coffee per unit area of land, strengthening information centers and system, and linking the farmers with cooperatives through membership by organizing and strengthening the cooperatives are recommended to increase coffee marketed surplus in the area.

\section{REFERENCES}

Abay Akalu. 2007. Vegetable market chain analysis in Amhara National Regional State: the case of Fogera woreda, South Gondar zone. M.Sc thesis presented to the school of graduate studies, Haramaya University. pp70.

Abraham Tegegn. 2013. "Value chain analysis of vegetables: the case of Habro and Kombolcha Woredas in Oromia region, Ethiopia". An MSc Thesis presented to the School of Graduate Studies of Haramaya University. 78p.

Aklilu, A., Ludi, E. 2010. The Effect of Global Coffee Price Changes on Rural Livelihoods and Natural Resource Management in Ethiopia. A Case Study from Jimma Area. NCCR North-South Dialogue, no. 26. Swiss peace Bern, Switzerland

Alemnewu Abay. 2010. Market chain analysis of red pepper: the case of Bure woreda, west Gojjam zone, Amhara National Regional State, Ethiopia. M.Sc thesis submitted to the school of graduate studies, Haramaya University. 91p.

Astewel Takele. 2010. Analysis of rice profitability and marketing chain: The case of Fogera Woreda, South Gondar Zone, Amhara National Regional State, Ethiopia. M.Sc thesis presented to School of Graduate Studies, Haramaya University. 76p.

Awol Zeberga. 2010. Analysis of poultry market chain: The case of Dale and Alaba 'special' woredas of SNNPRS, Ethiopia. M.Sc thesis presented to School of Graduate Studies, Haramaya University. p127.

Ayelech Tadesse. 2011. Market chain analysis of fruits for Gomma woreda, Jimma zone, Oromia National Regional State. M.Sc thesis presented to School of Graduate Studies, Haramaya University.p110.

BFED (Bureau of Finance and Economic Development). 2015. Seka Chokorsa district's Bureau of finance and economic development.

Bizualem, A., Degye, G. and Zekarias, S. 2015. Aalysis of marketed surplus of coffee by smallholder farmers in Jimma zone, Ethiopia. Journal of Biology, Agriculture and Healthcare, Vol.5, No.5, 2015

Cameron, C. and K. Trivedi. 2009. Microeconometrics using stata. A stata press publications, Stata Corps LP, Collage Stations, Texas.

CSA (Central Statistics Agency). 2014/2015. Agricultural sample survey report on area and production of crops (private peasant holdings, meher season). Volume I. CSA, Addis Ababa, Ethiopia. 18 pp.

Davison, J. 2000. Econometric theory. Oxiford: Blackwell. USA.

Desta Beyera. 2004. Impact of community managed irrigation on farm production efficiency and household income. The case of Weliso and Wenchi districts of Oromiya Regional State. M.Sc. Thesis Presented to the School of Graduate Studies, Haramaya University. 46p.

Elias A. 2005 Economics of Coffee Bean Marketing: A Case Study of Goma District in Jimma Zone of Ethiopia; Alemaya University

Fakoya, O., M. Agbonlahor and A. Dipeolu. 2007. Attitude of women farmers towards sustainable land management practices in South-Western Nigeria. World Journal of Agricultural Sciences, 3(4): 536-542.

FAOSTAT. 2011. FAO Statistical Year Book. http://faostat.fao.org/site/342/default.aspx

Gezahagn Kudama. 2010. Value chain analysis of groundnut in Eastern Ethiopia. M.Sc thesis submitted to the School of Graduate Studies, Haramaya University. 80p.

Greene, W. 2000. Econometric Analysis. $4^{\text {th }}$ edn. NJ: Prentice Hall, Englewwod Cliffs.

Gujarati, D. 2003. Basic Econometrics. $4^{\text {th }}$ edition. Tata McGraw-Hill Publishing Company Limited, New Delhi, India. $614 \mathrm{p}$.

IFPRI (International Food Policy Research Institute). 2015. Woreda-Level Crop Production Rankings in Ethiopia. Addis Ababa, Ethiopia

Jimma Zone Agricultural and Rural Development Office (JZARDO). 2008.” Annual Report for year 2007/08, Jimma." 
Kinde Aysheshm. 2007. Sesame market chain analysis: The case of Metema woreda, North Gondar Zone, Amhara National Regional State. M.Sc thesis presented to the School of Graduate Studies, Harmaya University. 102p.

Maddala, G.S. 2001. Introduction to Econometrics. Third Edition, John Will.

Muhammed Urgessa. 2011. Market chain analysis of teff and wheat production in halaba special woreda, southern Ethiopia. M.Sc thesis submitted to the School of Graduate Studies, Haramaya University. 104p.

Rehima Mussema. 2006. Analysis of red pepper marketing: The case of Alaba and Siltie in SNNPRS of Ethiopia. M.Sc thesis presented to the School of Graduate Studies, Haramaya University. 105p.

Tshiunza, M., J. Lemchi, A.Tenkouano. 2001. Determinants of market production of cooking banana in Nigeria. African Crop Science Journal, 9 (3): 537-547.

\section{AKNOWLEGMENT}

First of all, All praise be to Almighty God for giving me health, ability and strength for the completion of this article. Next, I would like to thank my Families, Relatives, Close friends and those individuals who helped me during the study conduction though they are not mentioned here specifically by name. Lastly, my special thanks go to Wollega University for the research fund including workers of the finance office for their immediate and supportive response in facilitating expedited disbursements.

\section{APPENDIXES}

Appendix table. The result of multicollinearity tests

\begin{tabular}{lll}
\hline Variables included in OLS model & & \\
\hline Variable & VIF & 1/VIF \\
\hline Coffee farming experience & 9.00 & 0.111 \\
Distance from the market & 8.38 & 0.119 \\
Family size & 5.30 & 0.189 \\
Membership to cooperatives & 3.36 & 0.297 \\
Land size & 3.07 & 0.326 \\
Ownership of transportation & 2.85 & 0.350 \\
Coffee market information & 2.83 & 0.353 \\
Livestock in TLU & 2.82 & 0.355 \\
Education of the households & 1.37 & 0.730 \\
Income from Non/Off-farm & 1.36 & 0.738 \\
Credit access & 1.35 & 0.741 \\
Sex of the household head & 1.18 & 0.850 \\
\hline Mean VIF & 3.57 & \\
\hline Source: Own computation results & & \\
\hline
\end{tabular}

Source: Own computation results, 2019

Appendix table. Test for heteroskedasticity Breusch-Pagan / Cook-Weisberg test for heteroskedasticity

Ho: Constant variance

Variables: fitted values of marketed surplus of coffee

$\operatorname{chi} 2(1)=0.33$

Prob $>$ chi $2=0.5674$

Appendix table. The test of specification error for omitted variables

Ramsey RESET test using powers of the fitted values of marketed surplus of coffee

Ho: model has no omitted variables

$\mathrm{F}(3,108)=2.08$

Prob $>\mathrm{F}=0.1065$ 
Appendix table. Conversion factors used to compute tropical livestock units (TLU)

\begin{tabular}{ll} 
Livestock Category & Conversion factor \\
\hline Calf & 0.25 \\
Weaned calf & 0.34 \\
Heifer & 0.75 \\
Cow or ox & 1.00 \\
Horse/mule & 1.10 \\
Donkey (adult) & 0.70 \\
Donkey (young) & 0.35 \\
Camel & 1.25 \\
Sheep or goat (adult) & 0.13 \\
Sheep or goat (young) & 0.06 \\
Chicken & 0.013 \\
Bull & 0.75 \\
\hline
\end{tabular}

Source: Storck et al., 1991

Appendix table. Conversion factor used to compute adult equivalent

\begin{tabular}{lll}
\hline Age group year & Male & Female \\
\hline$<10$ & 0.6 & 0.6 \\
$10-13$ & 0.9 & 0.8 \\
$14-16$ & 1 & 0.75 \\
$17-50$ & 1 & 0.75 \\
$>50$ & 1 & 0.75 \\
\hline
\end{tabular}

Source: Storck et al., 1991 